\title{
Evaluation of the interaction between TGF $\beta$ and nitric oxide in the mechanisms of progression of colon carcinoma
}

\author{
Sylvia Lohm ${ }^{1}$, Lucie Peduto-Eberl ${ }^{1}$, Patricia Lagadec ${ }^{2,4}$, Nicole Renggli-Zulliger ${ }^{3}$, Jean Dudler ${ }^{3}$, \\ Jean-François Jeannin ${ }^{2}$ \& Lucienne Juillerat-Jeanneret ${ }^{1}$ \\ ${ }^{1}$ University Institute of Pathology, Lausanne, Switzerland; ${ }^{2}$ Cancer Immunotherapy Research Laboratory, Ecole \\ Pratique des Hautes Etudes, INSERM U517, France; ${ }^{3}$ Division of Rhumatology, CHUV, Lausanne, Switzerland; \\ ${ }^{4}$ INSERM U256, Faculté de Médecine Pasteur, Nice, France
}

Received 12 May 2005; accepted in revised form 30 June 2005

Key words: cancer progression, colon carcinoma, endothelium, macrophages, nitric oxide, TGF $\beta$

\begin{abstract}
It is recognised that stromal cells determine cancer progression. We have previously shown that active TGF $\beta$ produced by rat colon carcinoma cells modulated NO production in rat endothelial cells. To elucidate the role of TGF $\beta$ and NO in the mechanisms of interaction of colon carcinoma cells with stromal cells and in cancer progression, we transfected REGb cells, a regressive colon carcinoma clone secreting latent TGF $\beta$, with a cDNA encoding for a constitutively-secreted active TGF $\beta$. Out of 20 injected rats only one tumour progressed, which was resected and sub-cultured (ReBeta cells). ReBeta cells secreted high levels of active TGF $\beta$. The adhesive properties of REGb and Rebeta cells to endothelial cells were similar, showing that the secretion of active TGF $\beta$ is not involved in tumour cell adhesion to endothelial cells. ReBeta, but not REGb, cell culture supernatants inhibited cytokine-dependent NO secretion by endothelial cells, but inhibition of NO production was similar in co-cultures of REGb or ReBeta cells with endothelial cells. Therefore, secretion of active TGF $\beta$ regulated endothelial NO synthase activity when tumour cells were distant from, but not in direct contact with, endothelial cells. However, only ReBeta cells inhibited cytokine-dependent secretion of NO in coculture with macrophages, indicating that the active-TGF $\beta$-NO axis confers an advantage for tumour cells in their interaction with macrophages rather than endothelial cells in cancer progression.
\end{abstract}

Abbreviations: BMDM - bone marrow-derived macrophages; CM - conditioned medium; DMEM - dulbecco's modified Eagle's medium; ELISA - enzyme-linked immunosorbent assay; FCS - fetal calf serum; IFN- $\gamma$ - interferon gamma; IL1 $\beta$ - interleukin-1beta; LPS - lippopolysaccharide; MMP - matrix metalloprotease; NO - nitric oxide; NOS - nitric oxide synthase; PBS - phosphate buffered saline; SD - standard deviation; TNF- $\alpha$ - tumour necrosis factor-alpha; TGF $\beta$ - transforming growth factor-beta

\section{Introduction}

To progress and successfully metastasise tumour cells have to resist defence mechanisms of the host organ stromal cells. Nitric oxide (NO) derived from macrophages and endothelial cells has been shown to reduce adhesion of tumour cells to endothelial cells and participates in tumouricidal activity against many types of tumours [1-8]. Cells, including macrophages and endothelial cells, express an inducible form of NO synthase (iNOS) [9] which has been involved in defence mechanisms against pathogens and tumour cells. Consequently, the capacity of tumour cells to modulate the

Correspondence to: Lucienne Juillerat-Jeanneret, University Institute of Pathology, Bugnon 25, CH-1011 Lausanne, Switzerland. Tel: +41-21-314-7173; Fax: +41-21-314-7115; E-mail: lucienne.juillerat @ chuv.hospvd.ch level of NO production at the metastasis site could be crucial in regulating adhesive properties and survival of tumour cells and may determine the outcome of cancer metastasis.

TGF $\beta$ has been involved in the mechanisms regulating tumour progression. However, the function of $\mathrm{TGF} \beta$ in cancer depends on the tumour stage and context [10]. In early stages TGF $\beta$ is anti-tumoural, inhibiting proliferation of tumour cells, whereas in later stages, TGF $\beta$ signalling pathways in tumour cells are inactivated. TGF $\beta$ then promotes cancer progression, acting as a permissive factor for stromal cells, inhibiting host immune surveillance, stimulating invasion, angiogenesis and metastasis. TGF $\beta$ also regulates protease secretion, including matrix metalloproteases (MMPs), or tumour cell interaction with endothelial cells [11-13]. We have previously shown that a progressive clone 
(PROb cells) of a chemically-induced rat colon carcinoma, secreting active TGF $\beta$ inhibited NO synthase induction and NO secretion in rat EC219 endothelial cells, whereas a regressive clone (REGb cells) isolated from the same colon carcinoma, secreting only latent TGF $\beta$ did not regulate NO production by EC219 cells [14]. In order to elucidate the role of tumour cell-derived $\mathrm{TGF} \beta$ in the TGF $\beta-\mathrm{NO}$ axis in cancer progression, we transfected REGb cells with a constitutively-secreted active form of TGF $\beta$ and evaluated the potential for these cells to form progressive tumours in vivo in tumour-cells syngeneic rats and to interact in vitro either with endothelial cells or macrophages expressing functional TGF $\beta$ receptors.

\section{Materials and methods}

\section{Cell lines}

The development and characterisation of the rat EC219 endothelial cell line have been described [15]. Cells were grown in Dulbecco's modified Eagle's medium (DMEM, $1 \mathrm{~g} / 1$ glucose; Life Technologies, Basel, Switzerland) supplemented with 10\% Fetal Calf Serum (FCS; Seromed, Fakola, Basel, Switzerland) and antibiotics on collagen type-I (Serva, Wallisellen, Switzerland) coated flasks. DHD/K12/TRs (referred to as REGb), a generous gift from Prof. F. Martin (INSERM, University of Dijon, France), is a sub-clone of the chemically induced rat colon carcinoma cell line $\mathrm{DHD} / \mathrm{K} 12$. REGb cells form regressive tumours when inoculated into syngeneic $\mathrm{BD}-\mathrm{IX}$ rats [16]. ReBeta cells are REGb cells which have been transfected with the cDNA encoding for active $\mathrm{TGF} \beta$ and selected in vivo (see below). REGb and ReBeta cells were grown in 1:1 DMEM-HAM-F12 (Life Technologies) supplemented with 10\% FCS and antibiotics. To prepare cell culture conditioned media (CM), cells were grown in culture media containing $10 \%$ FCS until reaching $75 \%$ confluence, then cultured for $48 \mathrm{~h}$ in serum-free culture medium. The culture supernatants were collected and spun for $10 \mathrm{~min}$ at $200 \times g$ and the supernatants recovered. CCL-64 cells (a kind gift from Dr K. Frei, Department of Neurosurgery, University Hospital Zurich, Switzerland) is a mink-lung epithelial cell line whose proliferation is inhibited by TGF $\beta$. CCL64 cells were grown in DMEM supplemented with 5\% FCS and $50 \mu \mathrm{M} \beta$-mercaptoethanol (Sigma, Buchs, Switzerland).

\section{Isolation and culture of bone marrow-derived macrophages}

Bone marrow-derived macrophages (BMDM) were isolated from the femur and tibia of adult rats (OFA) SPF; BRL, Füllingsdorf, Switzerland). The bone-heads were cut and the bone marrow was collected by rinsing the bone cavity with $5 \mathrm{ml}$ DMEM with a $25 \mathrm{G}$ needle. Resulting cell suspension was spun at $100 \times g$ for $5 \mathrm{~min}$.
Cells were cultured in Sterilin petri dishes (Bibby Sterilin, Ostermundigen, Switzerland) in a differentiation culture medium consisting of 50\% DMEM $1 \mathrm{~g} / 1 \mathrm{glu}-$ cose, $30 \%$ culture supernatant of L929 mouse fibroblasts and 20\% horse serum (Life Technologies) and antibiotics. After 7 days, cells were detached by incubation for $30 \mathrm{~min}$ at $4{ }^{\circ} \mathrm{C}$ and were further expanded in the differentiation culture medium for 5 days. BMDM were then washed with PBS and cultured in DMEM supplemented with $10 \%$ FCS for $24 \mathrm{~h}$, before performing experiments.

\section{Transfection of REGb cells}

Mutation of the Cys223 and Cys225 to Ser [17] induces the production of TGF $\beta 1$ peptides which do not associate with the latency associated peptide resulting in the secretion of constitutively biologically active TGF $\beta 1$. Five microgram of a PCRIII vector encoding mutated porcine TGF $\beta 1$, or a void vector as control, in $50 \mu \mathrm{l}$ of $20 \mathrm{mM}$ Hepes, pH 7.4 were adsorbed for $15 \mathrm{~min}$ at room temperature onto the DOTAP Liposomal Transfection Reagent (Roche Diagnostics, Rotkreuz, Switzerland) at $30 \mu \mathrm{g} / \mathrm{ml}$ final concentration under the conditions described by the provider. Then $5 \mathrm{ml}$ DMEM were added and the resulting suspension was added to half-confluent REGb cells. The cells were incubated for $4 \mathrm{~h}$ at $37^{\circ} \mathrm{C}$, washed and grown in DMEM containing 10\% FCS for 5 days. Then transfected cells were selected for 2 weeks in the presence of $800 \mu \mathrm{g} / \mathrm{ml}$ neomycin (Sigma), sub-cloned and grown in DMEM-HAM-F12 (1:1) containing 10\% FCS. The production of active TGF $\beta$ was measured using the CCL-64 cell growth-inhibition assay (see below).

\section{Animal experimentation}

Two clones of TGF $\beta$-transfected REGb cells were selected (see Table 1) depending on their level of secretion of active TGF $\beta$ (determined using the CCL-64 cell growth-inhibition assay) and on their capacity to inhibit iNOS activity in EC219 cells. Parental or transfected REGb cells (transfected either with a void vector or the vector containing the cDNA encoding active TGF $\beta$ ) were injected subcutaneously $\left(10^{6}\right.$ cells in $500 \mu$ l PBS per rat) into syngeneic BD-IX rats (10 rats/group; brothersister mated since 1971 in the laboratory of Prof. F. Martin). Tumour growth was evaluated weekly for 10 weeks by measuring width and length of the tumour mass using calipers. The rats were then sacrificed. As previously described, REGb cells always regressed when injected under these conditions [16]. The only growing tumor arising from the injection of active TGF $\beta 1$ transfected REGb cells was resected 10 weeks after injection, enzymatically digested to yield single cell suspension and expanded in vitro under the name ReBeta cells. Their secretion of active TGF $\beta$ was measured using the CCL-64 cell growth-inhibition assay and ELISA for active TGF $\beta$. 
Table 1. TGF $\beta$ secretion by colon carcinoma clones after transfection with constitutively-secreted active TGF $\beta$.

\begin{tabular}{llllll}
\hline & \multicolumn{2}{l}{ THF $\beta$-transfected REGb clones } & & \\
\cline { 2 - 6 } & 3 & 11 & 14 & 16 & 18 \\
\hline $\begin{array}{l}\text { CCL-64 cell growth inhibition } \\
\text { iNOS inhibition in EC 219 cells }\end{array}$ & ++ & + & + & + & + \\
$\quad \begin{array}{l}\text { Conditioned medium } \\
\text { Co-cultures }\end{array}$ & + & - & + & - & + \\
\hline
\end{tabular}

REGb transfected clones were grown to $75 \%$ confluence and culture medium was conditioned for 3 days in the absence of FCS. TGF $\beta$ content in the cell culture media was determined using either the CCL-64 growth inhibition assay, or the inhibition of NO secretion by EC219 cells or in cocultures of transfected cells with endothelial cells.

++ : High levels of active TGF $\beta ;+$ : medium levels of active TGF $\beta ;-$ : below detection limits; ND not determined.

\section{Inhibition of NO induction in EC219 cells}

These experiments were performed essentially as previously described [14]. Briefly, confluent EC219 cells were simultaneously exposed to $40 \mathrm{U} / \mathrm{ml}$ rat IFN- $\gamma($ rIFN- $\gamma$, Immunogenetics, Antwerpen, Belgium) and $200 \mathrm{U} / \mathrm{ml}$ murine TNF- $\alpha$ (mTNF- $\alpha$, Roche), respectively and, when indicated, the culture supernatants of untransfected or transfected REGb cells for $24 \mathrm{~h}$. Then NO secretion in the EC219 cell culture medium was quantified as nitrites using the Griess reagent as previously described [14]. To verify the induction of iNOS by cytokines in these cells, Western blotting experiments were performed using with an anti-mouse iNOS antibody (Transduction Laboratories, Basel, Switzerland).

\section{CCL-64 cell growth-inhibition assay for TGF $\beta$ quantification}

CCL-64 cells $\left(5 \times 10^{4}\right.$ per well) were incubated for $72 \mathrm{~h}$ at $37^{\circ} \mathrm{C}$ in 96 -well microtiter plates with serial dilutions of unknown samples or recombinant human TGF $\beta 1$ (rhTGF $\beta$; R\&D Systems, Abingdon, UK) at increasing concentrations $(5 \mathrm{pg} / \mathrm{ml}$ to $1 \mathrm{ng} / \mathrm{ml} \operatorname{rhTGF} \beta)$. Cell proliferation was assessed by addition of $250 \mu \mathrm{g} / \mathrm{ml}$ MTT [3-(4-5-dimethylthiazol-2-yl)-2,5-diphenyltetrazolium bromide] (Sigma) in DMEM during the last $2 \mathrm{~h}$. MTT crystals were dissolved with $0.04 \mathrm{~N} \mathrm{HCl}$ in isopropanol and optical density was measured at $540 \mathrm{~nm}$ in a multiwell microtiter plate reader (Labsystems iEMS Reader MF). TGF $\beta 1$ activity (pg/ml) in the samples was determined by comparison with a $\operatorname{rhTGF} \beta$ standard curve. Latent TGF $\beta$ was activated by heating the samples at $95{ }^{\circ} \mathrm{C}$ for $3 \mathrm{~min}$, as previously described [14], then active peptide determined using the CCL-64 cells.

\section{Determination of TGF $\beta$ protein level by ELISA}

Secreted TGF $\beta 1$ protein was measured in cell culture conditioned media using paired antibodies cross-reacting with rat and porcine TGF $\beta 1$ (R\&D Systems) according to the manufacturer's instructions. Ninetysix-well microtiter plates were coated with capture antibody (MAB 240; $4 \mu \mathrm{g} / \mathrm{ml}$ in $100 \mu \mathrm{l}$ PBS) and unknown or $\operatorname{rhTGF} \beta 1(5 \mathrm{pg} / \mathrm{ml}$ to $5 \mathrm{ng} / \mathrm{ml} \operatorname{rhTGF} \beta)$ diluted in $20 \mathrm{mM}$ Tris containing $150 \mathrm{mM} \mathrm{NaCl}, 0.1 \%$ BSA and $0.05 \%$ Tween 20 (diluent solution) were added and incubated for $2 \mathrm{~h}$ at room temperature, then biotinylated detection antibody (BAF 240; $50 \mathrm{ng} / \mathrm{ml}$ in diluent solution) was incubated for $2 \mathrm{~h}$ at room temperature. Quantification was done with peroxydasecoupled Streptavidin $(62.5 \mathrm{ng} / \mathrm{ml}$ in diluent solution, Zymed Laboratories, San Francisco, CA), $0.006 \% \mathrm{H}_{2} \mathrm{O}_{2}$ and $100 \mathrm{mg} / \mathrm{ml}$ tetramethylbenzidine (Sigma) in $0.05 \mathrm{M}$ phosphate-citrate buffer. The reaction was stopped with $0.5 \mathrm{M} \mathrm{H}_{2} \mathrm{SO}_{4}$ and optical density was measured at $450 \mathrm{~nm}$ using a reference filter at $620 \mathrm{~nm}$ in a multiwell microtiter plate reader (Labsystems). Concentrations of TGF $\beta 1$ in samples were calculated by comparison with a standard curve using $\operatorname{rhTGF} \beta$.

\section{$N O$ and TGFB secretion by REGb and ReBeta cells under cytokine stimulation}

Cells were exposed to $40 \mathrm{U} / \mathrm{ml}$ rIFN- $\gamma, 200 \mathrm{U} / \mathrm{ml}$ mTNF- $\alpha$ and $500 \mathrm{pg} / \mathrm{ml}$ rat IL- $1 \beta$ (rIL- $1 \beta$, R\&D system, Abingdon, UK) for $24 \mathrm{~h}$ and NO or TGF $\beta$ secretion in the cell culture medium was quantified as nitrites using the Griess reagent as previously described [14], or using the CCL-64 cell growth inhibition assay, for NO or TGF $\beta$, respectively.

\section{Co-cultures of tumour cells with of endothelial cells or macrophages}

EC219 endothelial cells were plated alone or together with either REGb or ReBeta tumour cells in 48-well plates $\left(2.5 \times 10^{4} \mathrm{EC} 219\right.$ cells and/or $5 \times 10^{4}$ tumour cells per well). Cells were allowed to adhere overnight at $37^{\circ} \mathrm{C}$ and stimulated with $40 \mathrm{U} / \mathrm{ml}$ rIFN- $\gamma$ plus $200 \mathrm{U} /$ $\mathrm{ml} \mathrm{mTNF}-\alpha$ for $24 \mathrm{~h}$ in complete culture medium. Culture supernatants were collected and nitrite concentrations determined using the Griess reagent [14]. Bone marrow-derived macrophages were plated in 48-well plates $24 \mathrm{~h}$ prior to addition of REGb or ReBeta tumour cells $\left(5 \times 10^{4}\right.$ cells per well). After $24 \mathrm{~h}$, cells were activated with $40 \mathrm{U} / \mathrm{ml} \mathrm{rIFN}-\gamma$ plus $100 \mathrm{ng} / \mathrm{ml}$ Lipopolysaccharide (LPS; Sigma) for $24 \mathrm{~h}$ in the presence of 
$10 \%$ FCS. Culture supernatants were collected and nitrite concentrations determined. Cultures of EC219, REGb or ReBeta cells or macrophages alone were used as controls.

\section{Adhesion assay}

EC219 cells in 48-well plates were either untreated or treated for $48 \mathrm{~h}$ with either $40 \mathrm{U} / \mathrm{ml} \mathrm{rIFN-} \gamma$ plus $100 \mathrm{U} /$ $\mathrm{ml} \mathrm{mTNF-} \alpha$ or with 4 and $2 \mathrm{ng} / \mathrm{ml}$ or $400 \mathrm{pg} / \mathrm{ml}$ $\operatorname{rhTGF} \beta$. Cells were washed twice with DMEM without FCS immediately prior to adhesion assay. REGb and ReBeta tumour cells were labelled with $400 \mathrm{nCi} / \mathrm{ml}$ $\left[{ }^{3} \mathrm{H}\right]$ thymidine (Amersham, Aylesbury, UK) for $10 \mathrm{~h}$ and detached for $1 \mathrm{~h}$ at $37^{\circ} \mathrm{C}$ with EDTA (Versene, Life Technologies). REGb or ReBeta tumour cells $\left(10^{5}\right.$ cells per well) were added to the EC219 cells in DMEM without FCS. After $30 \mathrm{~min}$ at $37^{\circ} \mathrm{C}$, non-adherent cells were removed, collected and spun for $10 \mathrm{~min}$ at $200 \times \mathrm{g}$. Adherent and non-adherent cells were dissolved overnight in $0.1 \% \mathrm{SDS} / 0.1 \mathrm{M} \mathrm{NaOH}$ and radioactivity was quantified in a $\beta$ counter (LKB Rackbeta, Helsinki, Finland).

\section{Zymogram analysis of gelatinase activity}

REGb-CM and ReBeta-CM supernatants were prepared as described above and concentrated 30-fold by centrifugation through a $5 \mathrm{kDa}$ cut-off polymer membrane (Millipore AG, Volketswil, Switzerland). Samples (25 $\mu \mathrm{g} /$ lane) were resolved without prior denaturation by electrophoresis in $10 \%$ SDS-polyacrylamide gel containing $1 \mathrm{mg} / \mathrm{ml}$ gelatin (Merck, Switzerland). As control, recombinant human MMP-2 (rhMMP-2; 4 ng/ lane; Oncogene Research Products, Luzern, Switzerland) was run in parallel. Following electrophoresis, gels were washed free of SDS with $2.5 \%$ Triton X-100 (Fluka, Buchs, Switzerland) and incubated at $37{ }^{\circ} \mathrm{C}$ for $24 \mathrm{~h}$ in $50 \mathrm{mM}$ Tris- $\mathrm{HCl} \mathrm{pH} 7.5$ containing $200 \mathrm{mM}$ $\mathrm{NaCl}, 5 \mathrm{mM} \mathrm{CaCl} 2$ and $0.02 \%$ Brij-35 (Fluka) and stained in with $0.05 \%$ Coomassie Brilliant Blue G-250 (Serva). MMP-2 activity was identified by its comigration with recombinant human MMP-2.

\section{Statistical evaluation}

Means, standard deviations (SD) and statistical significance were calculated using a paired Student's $t$-test.

\section{Results}

Rat REGb colon carcinoma cells were transfected either with the cDNA encoding constitutively-secreted active TGF $\beta 1$ or the empty vector as control. Transfected cells grew at the same rate than parental cells. Following 2 week selection and sub-cloning, constitutive secretion of active $\mathrm{TGF} \beta$ was measured in the culture supernatants of five different clones using the CCL-64 cell growth-inhibition assay, the inhibition of NO secretion by endothelial EC219 cells or by co-cultures of transfected REGb cells with endothelial cells (Table 1). Clone 3 produced very high levels of active TGF $\beta$, as assessed by strong inhibition of CCL-64 cell growth and of NO secretion by EC219 cells and were rejected for animal experimentation to avoid risks of fibrosis. Clones 11 and 16 produced low levels of active TGF $\beta$ using the CCL64 cell growth-inhibition assay and their conditioned media did not inhibit NO secretion by EC219 cells. Clones 14 and 18 secreted levels of active TGF $\beta$ that were able to inhibit CCL-64 cell growth and NO secretion by EC219 cells. Therefore these 2 clones were selected for further animal experimentation. Either REGb cells, REGb transfected with the empty vector (REGb control), clone 14 or clone 18 were sub-cutaneously (s.c.) injected into syngeneic rats. Injection of parental REGb cells, confirming previous results [16], or injection of cells transfected with the empty vector, always resulted in regressive tumours within 30 days. Out of 20 rats injected with clone 14 or clone 18 , only one tumour developed spontaneously from clone 14 (Figure 1). This tumour was resected, recultured under the name ReBeta cells and characterised.

The secretion of total (latent + active) TGF $\beta$ by ReBeta and REGb cells was measured using an ELISA (Table 2). As previously described [14], REGb cells secreted nearly detectable levels of active TGF $\beta$ whereas ReBeta cells secreted very high levels of TGF $\beta$. Active $\mathrm{TGF} \beta$ secretion under cytokine stimulation was also determined using the CCL-64-growth inhibition assay (Figure 2). rIFN- $\gamma$ alone did not modulate TGF $\beta$ secretion either by REGb or ReBeta cells. $\operatorname{rIFN}-\gamma$ in combination with mTNF- $\alpha$ did not modulate TGF $\beta$ secretion by REGb cells, but increased TGF $\beta$ secretion by ReBeta cells (Figure 2). The secretion of NO by REGb and ReBeta cells upon cytokine stimulation was also evaluated. Addition of $\operatorname{rIFN}-\gamma$ and $\operatorname{mTNF}-\alpha$

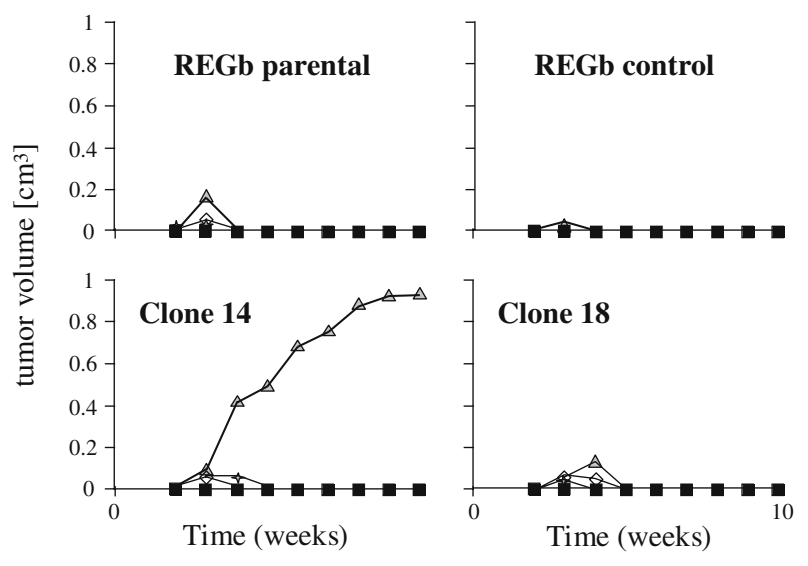

Figure 1. In vivo progression of REGb cells and cell clones. REGb cells $\left(10^{6}\right.$ cells per rat), either parental (REGb parental), or mock-transfected (REGb control), or transfected with constitutivelysecreted active TGF $\beta$ (clone 14 and clone 18) were injected subcutaneously in syngeneic BD-IX rats (10 rats per group). Tumour volume (in $\mathrm{cm}^{3}$ ) was evaluated weekly for 10 weeks. 
Table 2. ELISA determination of secretion of total (active + latent) TGF $\beta$ by REGb and ReBeta cells.

\begin{tabular}{lc}
\hline Conditioned media of tumor cells & TGF $\beta(\mathrm{pg} / \mathrm{ml})$ \\
\hline REGb-CM & $44 \pm 10$ \\
ReBeta-CM & $2926 \pm 50$ \\
\hline
\end{tabular}

Cells were grown to $75 \%$ confluence and culture medium was conditioned for 2 days in the absence of FCS. TGF $\beta$ secretion in the cell culture media was determined by a specific ELISA, and concentrations of TGF $\beta$ were calculated by comparison with $\operatorname{rhTGF} \beta$ as a standard. Values are the means of triplicate determinations \pm SD.

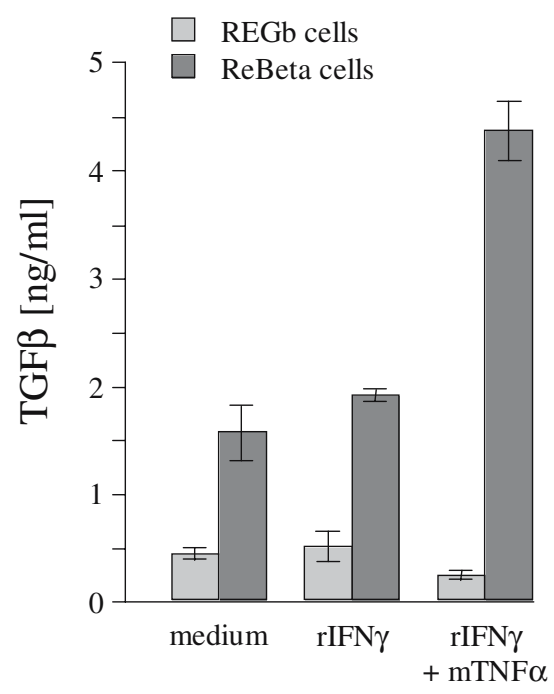

Figure 2. Secretion of TGF $\beta$ by cytokine-stimulated REGb and ReBeta cells. REGb (light grey bars) or ReBeta (dark grey bars) cells were grown to $60 \%$ confluence, and either not stimulated (medium) or stimulated with the indicated cytokines $(40 \mathrm{U} / \mathrm{ml} \mathrm{rIFN}-\gamma$, $100 \mathrm{U} / \mathrm{ml} \mathrm{mTNF}-\alpha$ ) for $48 \mathrm{~h}$ and active TGF $\beta$ secretion was quantified using the CCL-64 growth inhibition assay. Data are means of triplicate wells $\pm \mathrm{SD}$ of one representative experiment out of 3 .

resulted in a slight increase of NO secretion only by REGb cells, and the combination of rIFN- $\gamma, \operatorname{mTNF}-\alpha$ and IL- $1 \beta$ resulted in a significant increase of $\mathrm{NO}$ secretion by both cell lines $(P<0.01)$ although the cytokine-dependent increase of NO secreton by ReBeta cells was significantly lower than by REGb cells $(P<0.01)$ (Figure 3$)$. ReBeta and REGb cells secreted equivalent amounts of matrix metalloproteinase (MMP)-2, while secretion of MMP-9 was absent in both cells (Figure 4).

The effects of factors secreted by REGb and ReBeta cells on the secretion of NO by EC219 endothelial cells was evaluated. Treatment of EC219 endothelial cells with $40 \mathrm{U} / \mathrm{ml} \mathrm{rIFN}-\gamma$ and $100 \mathrm{U} / \mathrm{ml} \mathrm{mTNF}-\alpha$ for $24 \mathrm{~h}$ induced NO release (Figure 5), involving up-regulation of iNOS expression as determined by mRNA level or iNOS activity [14] or by Western Blot (Figure 5, insert). Addition of ReBeta-cell conditioned medium (ReBetaCM) to EC219 cells simultaneously with cytokines inhibited NO secretion whereas REGb-cell conditioned medium (REGb-CM) did not (Figure 5). Then the role of tumour cell-secretion of TGF $\beta$ on rapid adhesion of

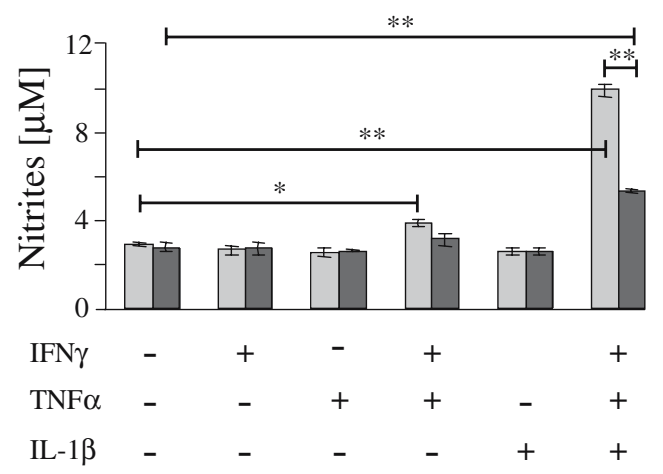

Figure 3. NO production by REGb and ReBeta cells under cytokine stimulation. REGb (light grey bars) or ReBeta (dark grey bars) cells were grown to $60 \%$ confluence, and either not stimulated $(-)$ or stimulated $(+)$ with the indicated cytokines $(40 \mathrm{U} / \mathrm{ml}$ rIFN- $\gamma$, $100 \mathrm{U} / \mathrm{ml} \mathrm{mTNF}-\alpha, 500 \mathrm{pg} / \mathrm{ml} \mathrm{rIL}-1 \beta$ ) for $48 \mathrm{~h}$ and NO secretion was determined. Statistical significance was assessed using a twotailed paired Student's $t$-test, *: $P<0.05$; **: $P<0.01$.

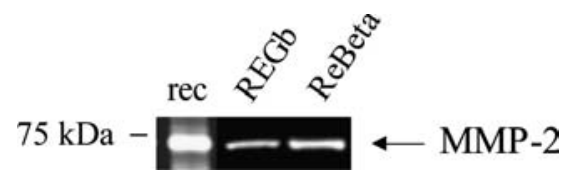

Figure 4. MMP-2 secretion by REGb and ReBeta cells. REGb and ReBeta cells were grown to sub-confluence and their culture media was conditioned for 2 days in the absence of FCS, concentrated and $25 \mu \mathrm{g}$ protein per lane were subjected to zymography. Recombinant MMP-2 was used as a standard.

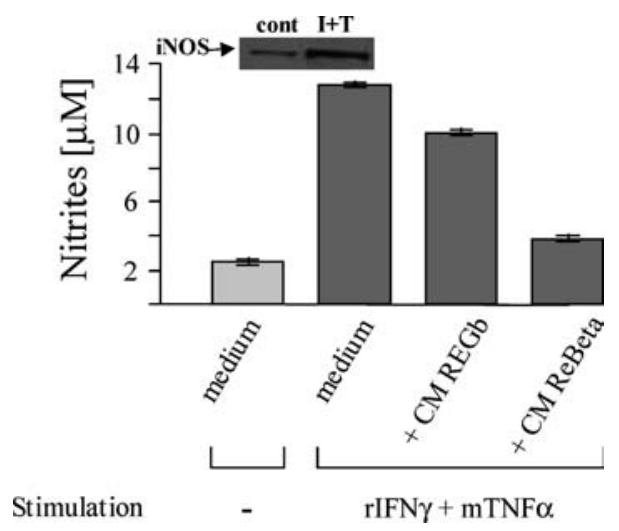

Figure 5. Effects of soluble factors secreted by REGb or ReBeta cells on NO production by endothelial cells. EC219 endothelial cells were grown to $60 \%$ confluence, and either not stimulated (medium, light grey bar) or stimulated with $40 \mathrm{U} / \mathrm{ml} \mathrm{IFN- \gamma}$ and $100 \mathrm{U} / \mathrm{ml}$ TNF- $\alpha$, in the absence (medium, dark grey bar) or the presence of either REGb (CM REGb, 50\% final concentration) or ReBeta conditioned medium (CM ReBeta, 50\% final concentration) for $24 \mathrm{~h}$ and NO secretion was determined. Data are means of triplicate wells $\pm \mathrm{SD}$ of one representative experiment out of 3 . Insert: The induction of iNOS protein by cytokine stimulation of EC219 cells was verified by Western blotting.

${ }^{3}$ H-Thymidine-labelled REGb or ReBeta cells to monolayers of endothelial cells was evaluated. REGb and ReBeta cells adhered similarly to EC219 cells (Figure 6a). Treatment of endothelial cells with $40 \mathrm{U} / \mathrm{ml}$ 

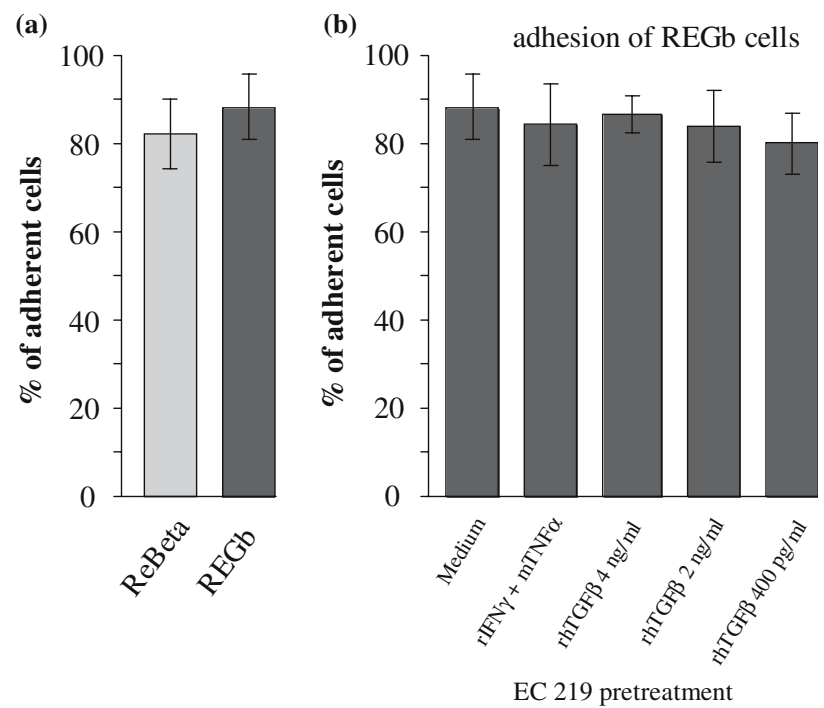

Figure 6. Adhesion of REGb or ReBeta cells to endothelial cells. (a) Unstimulated EC219 cells were exposed to ${ }^{3} \mathrm{H}$-Thymidine-labelled REGb or ReBeta cells for $30 \mathrm{~min}$, and adherent tumour cells were quantified. (b) EC219 cells were stimulated with $40 \mathrm{U} / \mathrm{ml} \mathrm{IFN- \gamma}$ and $100 \mathrm{U} / \mathrm{ml} \mathrm{TNF}-\alpha$, or with $\operatorname{rhTGF} \beta$ for $48 \mathrm{~h}$, then exposed for $30 \mathrm{~min}$ to ${ }^{3} \mathrm{H}$-Thymidine-labelled $\mathrm{REGb}$ or ReBeta (results not shown) cells, and adherent tumour cells were quantified. Results are means $\pm \mathrm{SD}$ of 3 independent experiments.

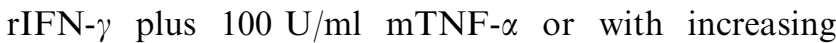
concentrations of $\mathrm{rhTGF} \beta(400 \mathrm{pg} / \mathrm{ml}$ up to $4 \mathrm{ng} / \mathrm{ml}$ $\operatorname{rhTGF} \beta$ ) for $48 \mathrm{~h}$ prior to adhesion assay did not modify their adhesive properties for either REGb (Figure $6 \mathrm{~b}$ ) or ReBeta cells (data not shown). In order to eliminate endothelial cell line-specific effects we performed similar experiments using another rat endothelial cell line, the CR3 cells [18], with similar information (results not shown). Next, the effect of direct contact between REGb or ReBeta cells with endothelial cells on the secretion of active or total TGF $\beta$ was quantified in the supernatant of co-cultures of EC219 cells with either REGb or ReBeta cells. EC219 cells did not secrete $\operatorname{TGF} \beta$, no active TGF $\beta$ and only low levels of latent TGF $\beta$ were detected in the supernatants of co-cultures of EC219 with REGb cells, whereas the secretion of active TGF $\beta$ in co-cultures of ReBeta cells with EC219 cells was decreased (Figure 7).

Finally the effect on NO secretion of direct contact between REGb or ReBeta cells and EC219 endothelial cells or bone marrow-derived macrophages was evaluated. Co-culture of EC219 endothelial cells with either REGb or ReBeta tumour cells did not modulate NO production in the absence of added cytokines (results not shown). However, NO production was inhibited when cytokine-stimulated EC219 cells were in co-cultures with either REGb or ReBeta cells (Figure 8). The inhibition of cytokine-induced NO production by EC219 cells can be reversed by addition of a blocking anti-TGF $\beta 1$ antibody [14] demonstrating the role of $\mathrm{TGF} \beta$ in the inhibition of NO secretion by EC219 cells. Addition of blocking anti-TGF $\beta 1$ antibody to the cocultures did not restore NO secretion by cytokine-

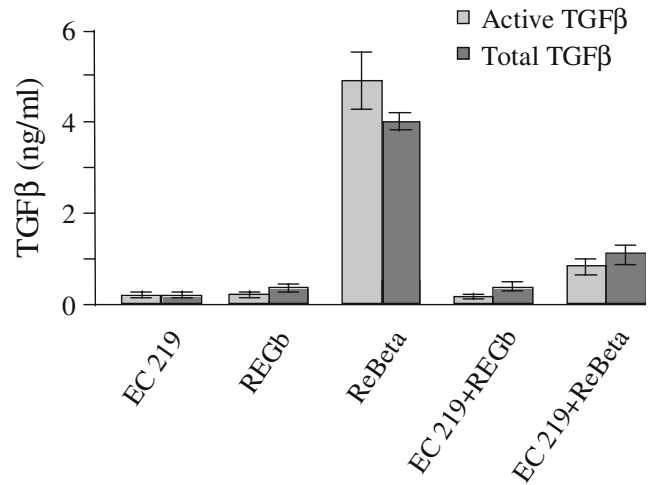

Figure 7. TGF $\beta$ secretion by co-cultures of endothelial cells and REGb or ReBeta cells. EC219, REGb or ReBeta cells were grown either alone (EC219, REGb, ReBeta) or in co-culture $(\mathrm{EC} 219+\mathrm{REGb}, \mathrm{EC} 219$ + ReBeta) for $24 \mathrm{~h}$, then stimulated with $40 \mathrm{U} / \mathrm{ml} \mathrm{IFN}-\gamma$ and $100 \mathrm{U} / \mathrm{ml} \mathrm{TNF}-\alpha$ for $24 \mathrm{~h}$, and active (light grey bars) and total (dark grey bars) TGF $\beta$ secretion was quantified using the CCL64 cell assay in the cell culture supernatants. Data are means of triplicate wells $\pm \mathrm{SD}$ of one representative experiment out of 3 .

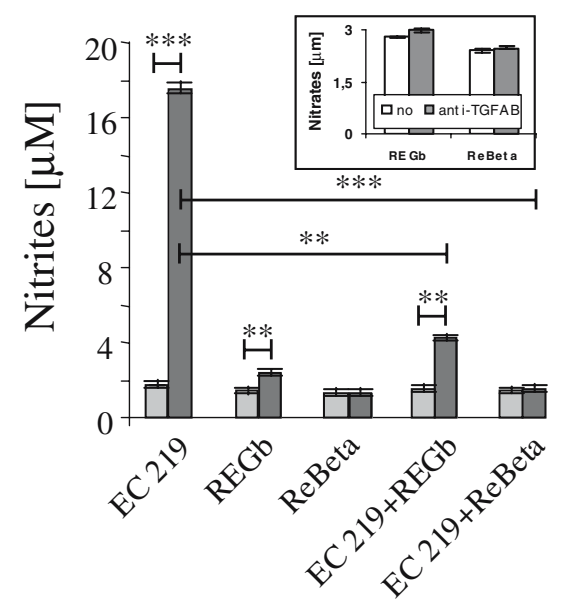

Figure 8. NO production in co-cultures of endothelial cells with either REGb or ReBeta cells. EC219, REGb or ReBeta cells were grown either alone (EC219, REGb, ReBeta) or in co-culture $(\mathrm{EC} 219+\mathrm{REGb}, \mathrm{EC} 219+\mathrm{ReBeta})$ for $24 \mathrm{~h}$, then either untreated

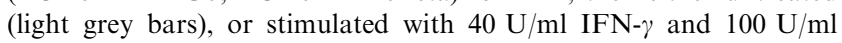
TNF- $\alpha$ (dark grey bars) for $24 \mathrm{~h}$, and NO secretion was determined. Statistical significance was assessed using a two-tailed paired Student's $t$-test, $*: P<0.05$; **: $P<0.01 ; * * *: P<0.001$. Results are means of duplicate wells \pm SD of one representative experiment out of 3. Insert: In co-cultures of EC219 cells with either REGb (REGb) or ReBeta (ReBeta) cells, addition of an anti-TGF $\beta$-blocking antibody did not restore NO secretion in response to cytokines. White bars: cytokines; grey bars: cytokines + anti-TGF $\beta$ antibody.

stimulated EC219 cells (Figure 8, insert). Activation of macrophages with $\operatorname{rIFN}-\gamma$ and LPS resulted in the secretion of large amounts of NO (Figure 9a). When macrophages were in contact with REGb cells, NO secretion was not modified, however in contact with ReBeta cells, NO secretion was inhibited, suggesting that the levels of active TGF $\beta$ secretion by colon carcinoma cells is involved in the regulation of production of NO by macrophage, but not by endothelial cells. Pre- 

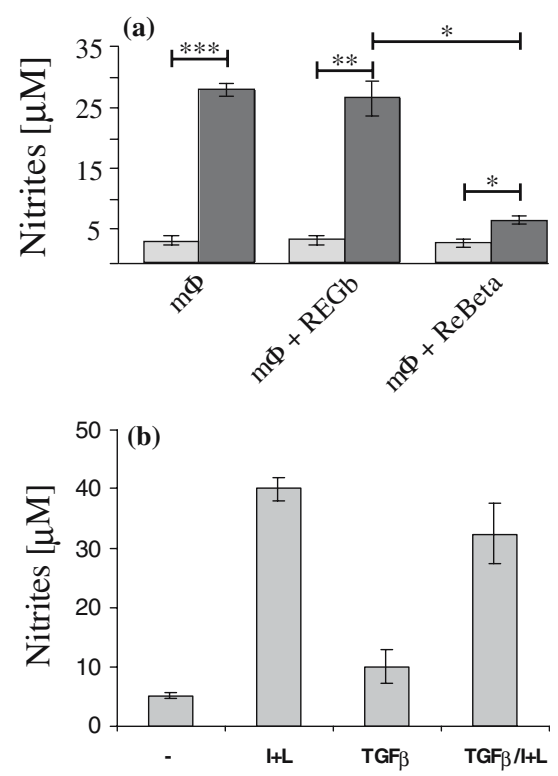

Figure 9. NO production by co-cultures of macrophages with either REGb or ReBeta cells. (a) Macrophages $(\mathrm{m} \Phi)$ were grown alone, or with either REGb or ReBeta ( $\mathrm{m} \Phi+\mathrm{REGb}, \mathrm{m} \Phi+$ ReBeta) cells for $24 \mathrm{~h}$, then either untreated (light grey bars) or treated with $40 \mathrm{U}$ $\mathrm{ml} \mathrm{IFN}-\gamma$ and $100 \mathrm{ng} / \mathrm{ml}$ LPS for $24 \mathrm{~h}$, and NO concentrations were measured in culture supernatants. Results are means $\pm \mathrm{SD}$ of triplicate wells of one representative experiment out of 3. Statistical significance was assessed using a two-tailed paired Student's $t$-test, $*: P<0.05$; **: $P<0.01$; ***: $P<0.001$. (b) Macrophages were either untreated or pre-treated for $24 \mathrm{~h}$ with $1.5 \mathrm{ng} / \mathrm{ml} \operatorname{rhTGF} \beta$ (TGB $\beta$ bars), then exposed either to culture medium (-, TGF $\beta$ ) or stimulated with $40 \mathrm{U} / \mathrm{ml} \mathrm{IFN-} \gamma$ and $100 \mathrm{ng} / \mathrm{ml}$ LPS for $24 \mathrm{~h}(\mathrm{I}+\mathrm{L}$, $\mathrm{TGF} \beta / \mathrm{I}+\mathrm{L}$ ), and NO concentrations were measured in culture supernatants. Results are means $\pm \mathrm{SD}$ of triplicate wells of one representative experiment out of 3 .

treatment of macrophages for $24 \mathrm{~h}$ prior to $\operatorname{rIFN}-\gamma$ and LPS stimulation was not able to inhibit their NO secretion (Figure 9b).

\section{Discussion}

TGF $\beta$ family ligands signal through a common mechanism bringing together type I and type II Ser/Thr kinase receptors, resulting in the phosporylation of type I receptor by type II receptor and activation of intracellular signalling pathways. Colon cancer cells predominantly produce $\operatorname{TGF} \beta$ in a latent form [19]. TGF $\beta$ is secreted as a latent complex of $290 \mathrm{kDa}$ consisting of bioactive TGF $\beta$ ( $\mathrm{Mr} 25 \mathrm{kDa}$ ), the latency-associated peptide (LAP; Mr $75 \mathrm{kDa}$ ), and the latent TGF $\beta$ binding protein 1 (LTBP1; Mr $190 \mathrm{kDa})$. LTBP1 is attached to LAP by a disulfide bond, which is required for the assembly and secretion of the latent TGF $\beta$ complex and prevents TGF $\beta$ signalling [20]. Mutations of Cys223 and Cys 225 to Ser in the propeptide region of TGF $\beta 1$ precursor [17] result in TGF $\beta 1$ peptides which do not associate to the LAP, and secretion of constitutively biologically active TGF $\beta 1$. TGF $\beta$ has been proposed to favour tumour progression in colon carcinoma but its contribution has not been clearly established. TGF $\beta$ is a potent growth inhibitor for normal epithelial cells, whereas in carcinoma cells, including colon cancer cells, mutations in the genes encoding TGF $\beta$ receptors frequently inactivate signalling [21]. TGF $\beta$ produced by tumour cells also exerts a paracrine effect on tumour stroma [12]. Therefore in the early stages of cancer $\mathrm{TGF} \beta$ is anti-tumoural, inhibiting proliferation of tumour cells, whereas in later stages, TGF $\beta$ rather promotes cancer progression by acting as a permissive factors for stromal cells to inhibit host immune surveillance, and stimulate invasion, angiogenesis and metastasis.

In the present experiments, in order to address the role of the interplay between $\operatorname{TGF} \beta$ and $\mathrm{NO}$ in cancer progression, we tested the hypothesis that the levels of active-TGF $\beta$ secretion by tumour cells is involved in stromal cell functions, particularly in modulating tumour cell interaction with endothelial cells and macrophages. To evaluate this hypothesis, we decided to perform in vivo selection of REGb cells engineered to secrete high levels of active $\operatorname{TGF} \beta$, then to perform in vitro studies, comparing REGb cells with active-TGF $\beta$ transfected REGb cells which had demonstrated the capacity for in vivo progression. Therefore REGb cells were transfected with a cDNA encoding constitutivelysecreted active TGF $\beta$ and these modified REGb cells were injected in syngeneic rats. The in vivo progression of tumour cells was evaluated and the interaction in vitro of a progressive tumour, ReBeta cells, with endothelial cells and macrophages was analysed in relation with tumour cell-dependent secretion of TGF $\beta$ and regulation of NO production.

Our results demonstrated that the secretion by colon carcinoma cells of high levels of active $\operatorname{TGF} \beta$ is not sufficient for a high incidence of tumour progression since out of 20 animals only one harboured a progressive tumour, which after resection still secreted high levels of TGF $\beta$. With the present approach we cannot ascertain whether the expression of the transfected peptide was maintained in the 19 animals which did not develop tumours. The autocrine secretion of high levels of active TGF $\beta$ did not inhibit growth of TGF $\beta$-transfected REGb cells, suggesting the loss of responsiveness of these cells for this effect of TGF $\beta$. After in vivo progression of TGF $\beta$-transfected REGb cells, cytokine activation further increased their TGF $\beta$ secretion, but decreased their production of NO compared to REGb cells. Levels of active TGF $\beta$ secretion in this model did not modify MMP-2 production, therefore excluding a role for TGF $\beta$ in promoting cancer progression via this pathway, which is in accordance with the information that tumour-associated fibroblasts are the main source of MMPs in tumours. NO has been shown to increase tumour cells adhesion to cytokine-stimulated endothelial cells [3], or to reduce tumour cell adhesion to postcapillary venules [6]. The cytokines TNF- $\alpha$ and IFN- $\gamma$ are known to increase adhesive properties of the endothelium. Treatment of endothelial cells with recombinant $\operatorname{TGF} \beta$ or exposure of endothelial cells to 
melanoma cells secreting latent TGF $\beta$ enhanced adhesion of tumour cells to endothelial cells [22]. Our present results demonstrated that the levels of active TGF $\beta$ secretion by colon carcinoma cells and the modulation by TGF $\beta$ of NO secretion by endothelial cells did not modify adhesive properties between endothelial and tumour cells, irrespective of cytokine stimulation of endothelial cells. In our model, the absence of modulation of tumour cells adhesion to cytokine-activated endothelial cells suggested that the interactions of colon carcinoma cells with endothelial cells are not based on the modulation by cytokines of the adhesive properties of adhesion molecules. In agreement with these results we have previously shown in a breast cancer model of lung metastasis that NO did not influence the early stages of tumour metastasis and the interaction of invading tumour cells with pulmonary endothelial cells, but that the cellular origin of $\mathrm{NO}$ was critical to the metastatic process [23]. Progressive colon carcinoma cells (PROb cells) secreting active TGF $\beta$ had the ability to inhibit cytokine-induced NO production in EC219 endothelial cells and microglial cells while a regressive clone (REGb cells) isolated from the same carcinoma but secreting only latent $\mathrm{TGF} \beta$ did not display these properties [14]. In PROb cells, regulation of NO secretion by TGF $\beta$ was an intracrine process, whereas exogeneously added TGF $\beta$ was ineffective [24].

The activation of latent TGF $\beta$ has been shown to be mediated by direct contact between endothelial and smooth muscle cells [25]. In co-cultures of EC219 with REGb or ReBeta cells, both cell lines behaved comparably, suggesting that latent $\mathrm{TGF} \beta$ could be activated through intercellular mechanisms. Tumour-cell derived IFN- $\beta$ stimulates NO production by host cells, including macrophages, and suppresses tumour progression [26]. TGF $\beta$ is able to block cytokine-mediated activation of macrophages and their NO secretion [27, 28] and is involved in the suppression of local immune response and NO-mediated macrophage cytotoxicity. Therefore tumour progression was inversely related to NO secretion by macrophages [29]. In our model, the level of TGF $\beta$ secretion, and the resulting modulation of NO secretion by macrophages was important in the mechanisms of interaction of colon carcinoma cells with macrophages. The decreased secretion of NO could be due to the blockade of macrophage activation by high levels of active TGF $\beta$ secreted by ReBeta cells, but not REGb cells. However, pre-exposure of macrophages to $\operatorname{rhTGF} \beta$ before $\operatorname{rIFN}-\gamma$ and LPS stimulation failed to mimic this inhibitory effect. These results suggest that continuous presence of high levels of $\operatorname{TGF} \beta$, as achieved in co-culture of macrophages with ReBeta cells, is necessary for this effect, or that direct contact, or alternatively that other molecules, are involved.

In conclusion, our study demonstrates that the secretion of high levels of active TGF $\beta$ is not sufficient to generally allow colon carcinoma cells to progress in vivo. These results also demonstrate that the adhesion of tumour cells to endothelial cells does not depend on the level of secretion of active TGF $\beta$ by tumour cells, suggesting that the NO-modulated adhesion of tumour cells to the endothelium is not a limiting factor for progression. The inhibition of NO production in macrophages depended on the level of active TGF $\beta$ secreted by tumour cells, indicating that immunomodulation of the host defence mechanisms by high TGF $\beta$ and the resulting modulation of the TGF $\beta-\mathrm{NO}$ axis may be related to tumour progression.

\section{Acknowledgements}

The authors thank the Swiss League against Cancer (Grants SKL 353-9-1996, KFS 947-09-1999 and KPS 1070-09-2000), the program "Co-tutelle de thèse" of the University of Lausanne and EPHE, the Programme d'Actions Intégrées Germaine de Stael and the Swiss Society for Multiple Sclerosis, for supporting these researches.

\section{References}

1. Leu RW, Leu NR, Shannon BJ et al. IFN- $\gamma$ differentially modulates the susceptibility of L1210 and P815 tumor targets for macrophage-mediated cytotoxicity. Role of macrophage-target interaction coupled to nitric oxide generation, but independent of tumor necrosis factor production. J Immunol 1999; 147: 1816-22.

2. Li LM, Kilbourn RG, Adams $\mathbf{J}$ et al. Role of nitric oxide in lysis of tumor cells by cytokine-activated endothelial cells. Cancer Res 1991; 51: 2531-5.

3. Vidal MJ, Zocchi MR, Poggi A et al. Involvement of nitric oxide in tumor cell adhesion to cytokine-activated endothelial cells. J Cardiovasc Pharmacol 1992; 20: S155-9.

4. Curley SA, Roh MS, Feig B et al. Mechanisms of Kupffer cell cytotoxicity in vitro against the syngeneic murine colon adenocarcinoma line MCA26. J Leukoc Biol 1993; 53: 715-21.

5. Dong Z, Staroselsky AH, Qi X et al. Inverse correlation between expression of inducible nitric oxide synthase activity and production of metastasis in K-1735 murine melanoma cells. Cancer Res 1994; 54: 789-93.

6. Kong L, Dunn GD, Keefer LK et al. Nitric oxide reduces tumor cell adhesion to isolated rat postcapillary venules. Clin Exp Metastasis 1996; 14: 335-43.

7. Murata J, Ricciardi-Castagnoli P, Dessous L'Eglise Mange P et al. Microglial cells induce cytotoxic effects toward colon carcinoma cells: Measurement of tumor cytotoxicity with a gammaglutamyl transpeptidase assay. Int J Cancer 1997; 70: 169-74.

8. Wink DA, Vodovotz Y, Laval $\mathbf{J}$ et al. The multifaceted roles of nitric oxide in cancer. Carcinogenesis 1998; 19: 711-21.

9. Moncada S, Palmer RMJ, Higgs EA. Nitric oxide: Physiology, pathology and pharmacology. Pharmacol Rev 1991; 43: 109-42.

10. Benson JR. Role of transforming growth factor beta in breast carcinigenesis. Lancet Oncol 2004; 5: 229-39.

11. Welch DR, Fabra A, Nakajima M. Transforming growth factor$\beta$ stimulates mammary adenocarcinoma cell invasion and metastatic potential. Proc Natl Acad Sci USA 1990; 87: 7678-82.

12. Chang HL, Gillett N, Figari I, Lopez AR, Palladino MA, Derynck $\mathrm{R}$. Increased transforming growth factor $\beta$ expression inhibits cell proliferation in vitro, yet increases tumorigenicity and tumor growth of meth A sarcoma cells. Cancer Res 1993; 53: 4391-8.

13. Shimizu S, Nishikawa $\mathrm{Y}$, Kuroda $\mathrm{K}$ et al. Involvement of transforming growth factor beta 1 in autocrine enhancement of gelatinase B secretion by murine metastatic colon carcinoma cells. Cancer Res 1996; 56: 3366-70. 
14. Murata J, Betz Corradin S, Felley-Bosco E et al. Involvement of a transforming-growth-factor- $\beta$-like molecule in tumor-cell-derived inhibition of nitric oxide synthesis in cerebral endothelial cells. Int J Cancer 1995; 62: 743-8.

15. Juillerat-Jeanneret L, Aguzzi A, Wiestler OD et al. Dexamethasone selectively regulates the activity of enzymatic markers of cerebral endothelial cell lines. In Vitro Cell Dev Biol 1992; 28A: 537-43.

16. Caignard A, Martin MF, Martin F. Interaction between two cellular sub-populations of a rat colonic carcinoma when inoculated to the syngeneic host. Int J Cancer 1985; 36: 273-9.

17. Brunner AM, Marquardt H, Malacko AR et al. Site-directed mutagenesis of cysteine residues in the pro region of transforming growth factor $\beta 1$ precursor. J Biol Chem 1989; 264: 13660-4.

18. Lechardeur D, Schwartz B, Paulin D et al. Induction of bloodbrain barrier differentiation in a rat brain-derived endothelial cell line. Exp Cell Res 1995; 220: 161-70.

19. Coffey RJ, Shipley GD, Moses H. Production of transforming growth factors by human colon cancer lines. Cancer Res 1986; 46 1164-9.

20. Derynck R, Akhurst RJ, Balmain A. TGF- $\beta$ signaling in tumor suppression and cancer progression. Nat Genet 2001; 29: 117-29.

21. Massagué J, Blain SW, Lo RS. TGF $\beta$ signaling in growth control, cancer and heritable disorders. Cell 2000; 103: 295-309.

22. Teti A, De Giorgi A, Spinella MT et al. Transforming growth factor- $\beta$ enhances adhesion of melanoma cells to the endothelium in vitro. Int J Cancer 1997; 72: 1013-20.
23. Gauthier N, Lohm S, Touzery C et al. Tumor-derived and hostderived nitric oxide differently regulate breast carcinoma metastasis to the lungs. Carcinogenesis 2004; 25: 1559-65.

24. Lagadec P, Raynal S, Lieubeau B et al. Evidence for control of nitric oxide synthesis by intracellular transforming growth factorb1 in tumor cells. Implications for tumor development. J Am Pathol 1999; 154: 1867-76.

25. Sato $\mathrm{Y}$, Okada F, Abe $\mathrm{M}$ et al. The mechanism for the activation of latent TGF- beta during co-culture of endothelial cells and smooth muscle cells: Cell-type specific targeting of latent TGF-beta to smooth muscle cells. J Cell Biol 1993; 123: 1249-54.

26. Wei D, Richardson EL, Zhu K et al. Direct demonstartion of negative regulation of tumor growth and metastasis by host inducible nitric oxide synthase. Cancer Res 2003; 63: 3855-9.

27. Corradin SB, Buchmuller-Rouiller Y, Smith J et al. Transforming growth factor beta 1 regulation of macrophage activation depends on triggering stimulus. J Leukoc Biol 1993; 54: 423-9.

28. Erwig LP, Kluth DC, Walsh GM et al. Initial cytokine exposure determines function of macrophages and renders them unresponsive to other cytokines. J Immunol 1998; 161: 1983-8.

29. Farias-Eisner R, Sherman MP, Aeberhald E et al. Nitric oxide is an important mediator for tumoricidal activity in vivo. Proc Nat Acad Sci USA 1994; 91: 9407-11. 